Original Research

\title{
Antimicrobial and Cytotoxicity Studies of Some Organotin(IV) $N$-ethyl- $N$-phenyl Dithiocarbamate Complexes
}

\author{
Jerry O. Adeyemi ${ }^{1,2}$, Damian C. Onwudiwe ${ }^{1,2 *}$ \\ ${ }^{1}$ Material Science Innovation and Modelling (MaSIM) Research Focus Area, Faculty of Natural and Agricultural \\ Science, North-West University (Mafikeng Campus), Mmabatho, South-Africa \\ ${ }^{2}$ Department of Chemistry, Faculty of Natural and Agricultural, Science, North-West University \\ (Mafikeng Campus), Mmabatho, South Africa
}

Received: 5 March 2019

Accepted: 24 July 2019

\begin{abstract}
Organotin(IV) dithiocarbamate complexes owe their uniqueness and properties to the individual attributes of the organotin and the dithiocarbamate moieties. The synergy exhibited by these groups often results in enhanced biological activities in the hybrid molecule. This study reports the biological activities (antimicrobial and cytotoxicity) of some organotin(IV) $\mathrm{N}$-ethyl- $\mathrm{N}$ phenyldithiocarbamate complexes presented as $\mathrm{MeSnClL}_{2}, \mathrm{BuSnClL}_{2}, \mathrm{PhSnClL}_{2} \mathrm{Me}_{2} \mathrm{SnL}_{2}, \mathrm{Bu}_{2} \mathrm{SnL}_{2}$, and $\mathrm{Ph}_{2} \mathrm{SnL}_{2}(\mathrm{~L}=N$-ethyl- $N$-phenyl dithiocarbamate). Their antimicrobial properties were studied against K. pneumonia, S. aureus, E. coli, P. aeruginosa, B. cerues, A. flavus and C. albican, and the results revealed varied activity of good to moderate properties. Complex $\mathrm{PhSnClL}_{2}$ and $\mathrm{Ph}_{2} \mathrm{SnL}_{2}$ showed the highest activities among this group of complexes due to the presence of planar phenyl group(s) within the organotin moiety, which enhances the lipophilicity of the complexes and subsequent penetration into the organisms. The complexes were further screened for cytotoxicity using the MTT assay method against the human cervical cancer cell line (HeLa cells). A remarkable anti-tumoral activity, especially for complex PhSnClL $\mathrm{P}_{2}$ and $\mathrm{Ph}_{2} \mathrm{SnL}_{2}$, were observed when compared to 5-Fluorouracil (5FU). The studies showed that upon further optimization, these complexes could become a leading class of compounds that possess broad-spectrum antimicrobial and anti-tumoral activities.
\end{abstract}

Keywords: organotin(IV), dithiocarbamate, cytotoxicity, antimicrobial

\section{Introduction}

Different approaches to drug discovery have arisen due to the evolution of new diseases, loss in activity of

*e-mail: Damian.Onwudiwe@nwu.ac.za known drugs, and the resistance of pathogens to already used drugs. Some of these methods are carried out by organic chemists and involve a synthetic approach, the development of structural analogues of existing drugs, fortuitous identification, and metal complex therapy, etc. [1]. Metal complex formation has provided a therapeutic platform [2] for making innovative and novel drugs 
to tackle new emerging diseases [3], and also combat resistance in some cases. They are formed when a metal atom is bonded to one or more Lewis bases (the ligand). The types of coordinated ligands, the oxidation state, and the coordination geometry of the complexes could be useful for identifying a variety of properties [4]. These diverse properties could influence the identity without altering the very nature of the organic fragment (ligand) in the search for the formation of new analogues [5]. A broadly studied example of these types of compound is metal dithiocarbamate complexes.

Many transition metal dithiocarbamate complexes have shown to have useful biological potential [6, 7]. However, their main group counterparts such as tin are less explored. Among the few that have been reported, organotin(IV) dithiocarbamate complexes have shown to have useful biological potential [8-11]. The dithiocarbamate group, the organotin moiety, and the coordination number of the central metal in these complexes play important roles in determining their usefulness as biological agents [12]. Furthermore, the chelation effect due to the polarity of the metal ion also plays a crucial role in their biological property. Upon complexation, the polarity of the metal center is considerably reduced as a result of the delocalization of electrons over the chelate ring and the partial sharing of the positive charge with donor groups [13]. This, consequently, increases lipophilicity and enhances the complex uptake into the cells through the lipid layer of the cell membrane. This inflow creates a disturbance in the respiratory process of the cells, and in turn affects protein synthesis, which ultimately impedes the growth of the cells [13].

Some derivatives of coordination compounds containing different organotin(IV) and dithiocarbamate moieties have been synthesized, and their anti-cancer [14-16], antimicrobial [12, 17-20], and antiradical properties [15] have been reported. Significant antitumoral and antimicrobial potential have been reported in the following order: $\mathrm{R}_{3} \mathrm{Sn}^{+}>\mathrm{R}_{2} \mathrm{Sn}^{2+}>\mathrm{RSn}^{3+}$ [15], which shows that the length and number of the alkyl groups attached to the tin center could influence the biological activities of these compounds. However, selectivity of the complexes toward the screened cells has been found to also affect this order $[15,21]$. The interaction of the bulky phenyl group, for insatnce, with biomolecules within a cell, can be achieved via $\pi-\pi$ interactions due to the high lipophilicity observed for the phenyl group. As a result of the lipophilicity, organotin(IV) compounds can easily interact with cellular membranes as well as cytoplasmic membranes [22]. The useful biological properties observed is not only limited to the presence of the organotin(IV) groups, but also to the dithiocarbamate ligands. The sulfur atoms (as donor sites) in the dithiocarbamate ligand contributes immensely to the unique stereo-electronic properties of organotin(IV) dithiocarbamate complexes that play an important role in the transportation of molecules to the targeted sites, as well as the enhancement of retention time $[23,24]$. One notable role of the dithiocarbamate group in their usage as biologically useful compounds is their ability to effectively modulate the excess toxicity associated with the organotin(IV) group, which may become harmful with increased potency [23].

Since the useful functionalities of organotin(IV) dithiocarbamate complexes in a biological system originate from the synergy created by the individual properties of the organotin(IV) and the dithiocarbamate moieties respectively [25], their unique properties continue to inspire research interest. In this report, we present a biological study involving antimicrobial and cytotoxicity activity of some organotin(IV) $\mathrm{N}$-ethyl$\mathrm{N}$-phenyldithiocarbamate complexes reported in our previous work [26].

\section{Experimental}

\section{Materials and Methods}

All organotin(IV) $N$-ethyl- $N$-phenyldithiocarbamate complexes $\left(\mathrm{MeSnClL}_{2}, \mathrm{BuSnClL}_{2}, \mathrm{PhSnClL}_{2} \mathrm{Me}_{2} \mathrm{SnL}_{2}\right.$, $\mathrm{Bu}_{2} \mathrm{SnL}_{2}$, and $\mathrm{Ph}_{2} \mathrm{SnL}_{2}$ ), their Synthesis procedure and characterization have been reported in our previous study [26].

\section{Antimicrobial Analysis}

Microbial strains of five bacterial ( $S$. aureus, $B$. cereus, $P$. aeruginosa, E. coli, K. pneumonia) and two fungi (A. flavus and $C$. albicans), selected based on their clinical and pharmacological relevance, were collected from the Microbiology Department of the Federal Teaching Hospital in Abakaliki, Nigeria [27]. This study was achieved using the agar well diffusion method [28]. Sterile Muller-Hinton agar was used to prepare the petri plates by the streaking of the test cultures $\left(10^{6} \mathrm{CFU} / \mathrm{mL}\right)$ on the condensed agar in petri plates and allowing them to dry for $15 \mathrm{~min}$. This was done in order to achieve a uniform thick layer of growth. Stock solution of the complexes at 10, 25 and $50 \mu \mathrm{g} / \mathrm{mL}$ were prepared using $80 \%$ dimethylsulfoxide as a diluent $[29,30]$. Wells of about $6 \mathrm{~mm}$ were bored into the solid agar with the help of a cork, followed by the filling of $25 \mu \mathrm{L}$ of the sample stock solutions with the help of a micro pipette. On each plate, 3-(4, 5-dimethylthiazol-2yl)-2, 5-diphenyltetrazolium bromide (MTT) $(20 \mu \mathrm{L}$ of $1.25 \mathrm{mg} / \mathrm{mL}$ ) was added to give a purple colouration. These plates were then incubated at $37^{\circ} \mathrm{C}$ for $24 \mathrm{~h}$ for the bacteria strains, and at $30^{\circ} \mathrm{C}$ for $48 \mathrm{~h}$ for the fungi strains. Both Sulfamethoxazole (an antibacterial drug) and Ketoconazole (an antifungal drug) were used as positive controls for the antibacterial and antifungal studies respectively. The diluent (80\% DMSO) was used as a negative control. Inhibition zones were measured in millimeters and the experiment was repeated four times. The results obtained were reported as mean \pm S.D. of the four measurements. The activity of the samples 
were determined by measuring the diameter of the inhibitory zones on the surface of the agar around the bored wells.

\section{Cytotoxicity Analysis (MTT Assay)}

The cells used for this study were the Human cervical carcinomas cells (HeLa). They were acquired from ATCC, USA. These cells were cultured in EMEM (Belgium) in a culture flask $\left(25 \mathrm{~cm}^{3}\right)$ that contained $100 \mathrm{U} \mathrm{mL}^{-1}$ penicillin, $10 \%$ fetal bovine serum and $100 \mu \mathrm{gmL}^{-1}$ streptomycin. The viability of the cells were ascertained using MTT assay in a 96-well plate containing $2.5 \times 102$ cells/well in $100 \mu \mathrm{L}$ EMEM. They were then incubated at $37^{\circ} \mathrm{C}$ for $15 \mathrm{~h}$, and the medium was replaced along with the addition of complexes at different concentrations of $25,50,100$, and $150 \mu \mathrm{g} / \mathrm{mL}$. They were further incubated at $37^{\circ} \mathrm{C}$ for another $48 \mathrm{~h}$, followed by the MTT assay. Untreated cells were used as positive control and 5-Fluorouracil was also used as a standard. In the assay, the medium was changed to one containing $10 \%$ MTT reagent $(5 \mathrm{mg} / \mathrm{mL}$ in PBS), and incubated at $37^{\circ} \mathrm{C}$ for $4 \mathrm{~h}$. Subsequently, this assay was removed and the formazan crystals were dissolved in DMSO $(100 \mu \mathrm{L})$, followed by the absorbance reading in a Mindray MR-96A microplate reader at $570 \mathrm{~nm}$ using DMSO as a blank. These assays were carried out in quadruplet.

\section{Results and Discussion}

\section{Antimicrobial Studies}

All the compounds synthesized were screened against bacterial strains (Gram positive (+): B. cerues, S. aureus; and Gram negative (-): E. coli, $P$. aeruginosa, $K$. pneumonia) and fungi strains (A. flavus and C. albican). This screening was conducted in three different concentrations of 10, 25,
$50 \mu \mathrm{g} / \mathrm{mL}$. The obtained results were taken as a measure of antimicrobial potential. Furthermore, no significant activity was observed at 10 and $25 \mu \mathrm{g} / \mathrm{mL}$. However, the complexes showed appreciable activities at $50 \mu \mathrm{g} / \mathrm{mL}$ and these results have been presented in Table 1 and summarized in Fig. 1. The halos formed around the bored wells were the measure of the sample inhibition on the screened microorganism and these were classified accordingly as: $1-9 \mathrm{~mm}$, weakly active; 10-13 mm, moderately active; $13-17 \mathrm{~mm}$, active; and above $17 \mathrm{~mm}$, very active [31, 32].

Generally, all the complexes showed better activity than the parent ligand, which exhibited no activity at $50 \mu \mathrm{g} / \mathrm{mL}$. The dissimilarity in the antimicrobial activities for these groups of complexes with the same ligand showed that some of them are specific to a particular group of bacteria [33]. Hence, from the observed activities, both the bacteria and fungi used were very susceptible to the compounds, and their activities ranged from moderate to good. These activities have been collectively attributed to complexation based on Overton's concept and Tweedy's chelation theory [34]. Overton's concept suggests that lipid-soluble compounds are generally favored by lipid membranes [34], while Tweedy's chelation theory suggests that the polarities of metal ions are reduced in complexes. Tweedy's theory thus implies that the tendency for lipophilicity is enhanced in the chelate ring with the metal center and favors permeation into the cell membranes [35].

The activities may also be attributed to the intrinsic biological effects of organotin(IV) moiety [36, 37]. The partial sharing of positive charge of the metal ion with the sulfur donor atoms and the overlapping of the ligand's orbitals with consequent electron delocalization over the whole chelate are the two main factors that contribute to the reduction in polarity of the metal center [34]. All the phenyltin(IV) derivatives in the $N$-ethyl- $N$-phenyl dithiocarbamate compounds $\left(\mathrm{PhSnClL}_{2}\right.$ and $\left.\mathrm{Ph}_{2} \mathrm{SnL}_{2}\right)$, showed useful

Table 1. Summary of antimicrobial screening of complexes

\begin{tabular}{|c|c|c|c|c|c|c|c|}
\hline Compounds & P. aeruginosa & E. Coli & K. pneumonia & S. aureus & B. cerues & A. flavus & C. albican \\
\hline $\mathrm{L}$ & na & na & na & na & na & na & na \\
\hline SFMT & $28 \pm 0.0$ & $30 \pm 0.4$ & $26 \pm 0.0$ & $23 \pm 0.7$ & $26 \pm 0.4$ & na & na \\
\hline$(\mathrm{KTCZ}$ & na & na & na & na & na & $22 \pm 0.7$ & $27 \pm 0.7$ \\
\hline $\mathrm{MeSnClL}_{2}$ & na & $17 \pm 2.1$ & $14 \pm 0.0$ & $08 \pm 1.4$ & na & $10 \pm 0.4$ & $10 \pm 2.1$ \\
\hline $\mathrm{BuSnClL}_{2}$ & $18 \pm 0.7$ & $21 \pm 0.0$ & $19 \pm 0.0$ & $14 \pm 0.7$ & na & $11 \pm 1.4$ & $15 \pm 0.7$ \\
\hline $\mathrm{PhSnClL}_{2}$ & $20 \pm 0.0$ & $18 \pm 0.7$ & $19 \pm 0.7$ & $15 \pm 0.7$ & $10 \pm 0.7$ & $17 \pm 0.4$ & $14 \pm 0.4$ \\
\hline $\mathrm{Me}_{2} \mathrm{SnL}_{2}$ & na & $11 \pm 0.4$ & na & $11 \pm 0.7$ & na & na & na \\
\hline $\mathrm{Bu}_{2} \mathrm{SnL}_{2}$ & $20 \pm 0.4$ & $19 \pm 0.4$ & $19 \pm 2.1$ & $13 \pm 1.4$ & $10 \pm 1.4$ & $14 \pm 0.4$ & $11 \pm 0.4$ \\
\hline $\mathrm{Ph}_{2} \mathrm{SnL}_{2}$ & $18 \pm 0.0$ & $23 \pm 0.4$ & $23 \pm 0.4$ & $16 \pm 0.0$ & $13 \pm 0.4$ & $16 \pm 0.7$ & $15 \pm 0.4$ \\
\hline
\end{tabular}

$50 \mu \mathrm{g} / \mathrm{mL}$ (quadruplet results); na $=$ not active 


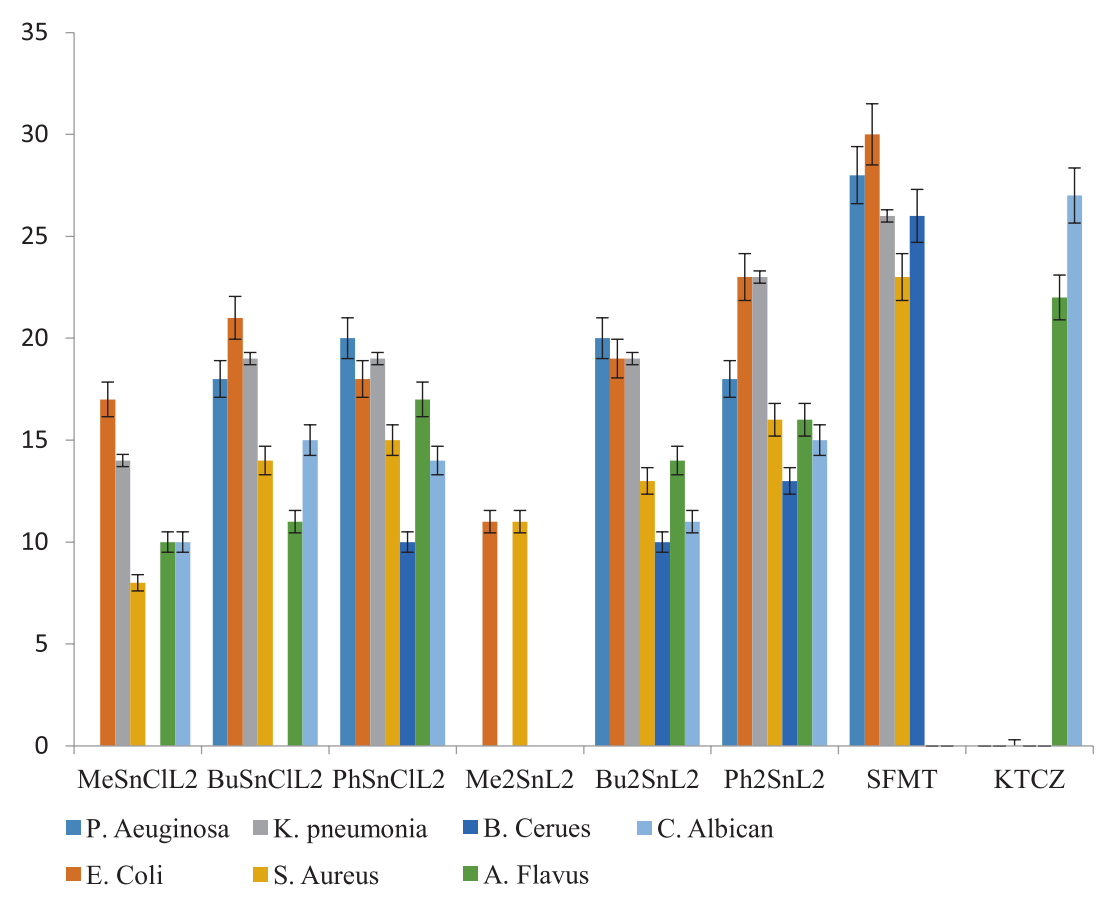

Fig. 1. Histogram showing the antimicrobial activities of the organotin(IV) $N$-ethyl- $N$-phenyl dithiocarbamate complexes.

activity, which ranged from moderate to very active antimicrobial activity when compared to both standard drugs used for the screened bacteria and fungi organisms. These may be due to the increased lipophilicity originating from the presence of the phenyl group in the organotin moiety, thereby causing a favorable inflow of the complexes through the lipid bilayer of the bacteria organisms [38]. However, the disubstituted organotin complexes showed better activity than their mono-substituted counterpart, which is in agreement with what has been reported in the literature [39]. Thus, the antimicrobial activity is structuredependent and follows the pattern:

$$
\begin{gathered}
\mathrm{Me}_{2} \mathrm{SnL}_{2}<\mathrm{MeSnClL}_{2}<\mathrm{BuSnClL}_{2}< \\
\mathrm{Bu}_{2} \mathrm{SnL}_{2}<\mathrm{PhSnClL}_{2}<\mathrm{Ph}_{2} \mathrm{SnL}_{2}
\end{gathered}
$$

This observed pattern also suggested higher susceptibility for the Gram negative (-) than the Gram positive (+) bacteria, due to the structural differences in the cell walls and membranes of both groups of bacteria. In Gram positive (+) bacteria, the presence of a cell wall does not allow for easy penetration because of an outer lipid membrane (originating from lipopolysaccharide) which contributes to the antigenic specificity of these organisms [40-43]. The Gram negative (-) bacteria only has a simpler cell membrane (that lacks the rigidity of the cell wall), which made them more susceptible to the complexes than the Gram positive ( + ) bacteria. $\mathrm{Me}_{2} \mathrm{SnL}_{2}$ and $\mathrm{MeSnClL}_{2}$ showed the weakest activities due to the small size of the methyl group. However, due to selectivity, $\mathrm{Me}_{2} \mathrm{SnL}_{2}$ exhibited weaker activity compared to $\mathrm{MeSnClL}_{2}$, which contradicted the expected structural relationship.
The mode of action as suggested for compounds containing the azomethine group $(>\mathrm{C}=\mathrm{N})$ may involve hydrogen bond formation with the active center of the cell constituents through the azomethine group, which consequently interferes with the cell process and ultimately results in death [44]. In addition, the number of the chloride ions in the organotin(IV) moiety play a key role in the antimicrobial activity of the complexes [39]. From this study, the organotin complexes with a single chloride ion showed lower activity compared to their counterpart without the chloride ion. This correlates well with other reports on the bactericidal activities of this class of compounds with a similar number and type of organic groups bonded to the $\mathrm{Sn}(\mathrm{IV})$-center $\left(\mathrm{R}_{3} \mathrm{Sn}^{+}>\mathrm{R}_{2} \mathrm{Sn}_{2}{ }^{+}>\mathrm{RSn}_{3}{ }^{+}>\mathrm{Sn}_{4}{ }^{+}\right.$, bactericidal activity and toxicity scale) [39]. It is also possible for the biological activity of organotin complexes to decrease if the alkyl moiety attached to the tin metal is too large (e.g, octyl group) or too small (e.g, methyl group). Therefore, in the search for an organotin complex with useful antimicrobial properties, the ratio between the lipophilicity and solubility properties of these complexes in an organism are an important factor to be considered [45]. One major improvement often associated with the replacement of the chloride ion with an organic ligand is the reduction in the side effect, such as toxicity, which could also reduce antimicrobial activity. Hence, a right balance for the substitution and the availability of the chloride ion is needed.

\section{Cytotoxicity Studies}

HeLa cell is an immortal cell line obtained from a common human cervical cancer cell [21]. In this 
Table 2. Viabilities (\%) of the HeLa cell lines at different concentrations for the complexes.

\begin{tabular}{|c|c|c|c|c|c|}
\hline $\mathrm{No}$ & $25 \mu \mathrm{g} \mathrm{mL}^{-1}$ & $50 \mu \mathrm{g} \mathrm{mL}^{-1}$ & $100 \mu \mathrm{g} \mathrm{mL}^{-1}$ & $150 \mu \mathrm{gLL}^{-1}$ & $\mathrm{IC}_{50}$ \\
\hline $\mathrm{MeSnClL}_{2}$ & $83.14 \pm 3.22$ & $82.21 \pm 3.08$ & $81.38 \pm 6.54$ & $80.54 \pm 1.27$ & $>\mathbf{4 0 0 0}$ \\
\hline $\mathrm{BuSnClL}_{2}$ & $36.28 \pm 3.15$ & $33.23 \pm 10.00$ & $21.22 \pm 13.33$ & $21.33 \pm 14.54$ & $\mathbf{8 . 1 2}$ \\
\hline $\mathrm{PhSnClL}_{2}$ & $32.23 \pm 8.32$ & $25.18 \pm 21.23$ & $27.98 \pm 14.20$ & $25.18 \pm 18.55$ & $\mathbf{4 . 3 7}$ \\
\hline $\mathrm{Me}_{2} \mathrm{SnL}_{2}$ & $31.13 \pm 10.67$ & $30.44 \pm 2.24$ & $31.28 \pm 5.49$ & $30.21 \pm 13.06$ & $\mathbf{1 2 . 3 0}$ \\
\hline $\mathrm{Bu}_{2} \mathrm{SnL}_{2}$ & $41.68 \pm 5.61$ & $39.78 \pm 14.60$ & $30.62 \pm 13.75$ & $26.56 \pm 14.37$ & $\mathbf{1 1 . 7 5}$ \\
\hline $\mathrm{Ph}_{2} \mathrm{SnL}_{2}$ & $32.33 \pm 6.10$ & $30.65 \pm 9.01$ & $29.30 \pm 7.17$ & $28.16 \pm 8.25$ & $\mathbf{0 . 0 1}$ \\
\hline $\mathbf{C o n t r o l ~ 1}^{\mathbf{C o n t r o l ~ 2}}$ & $100.00 \pm 0.68$ & $100.00 \pm 0.51$ & $100.00 \pm 0.79$ & $100.00 \pm 0.79$ & -- \\
\hline $\mathbf{5 F U}$ & $103.09 \pm 1.43$ & $105.01 \pm 2.43$ & $104.09 \pm 2.43$ & $104.09 \pm 2.43$ & -- \\
\hline
\end{tabular}

study, the $\mathrm{IC}_{50}$ values for the compounds obtained are summarized in Table 2. These results suggested a concentration-dependent profile with some outstanding activity toward the used cell line. Furthermore, cytoselectivity toward the used cell line was also observed for the complexes, and some of the activity (in $\mathrm{IC}_{50}$ ) obtained were better compared to the standard drug (5-Fluorouracil (5FU)), with an $\mathrm{IC}_{50}$ value of $40 \mu \mathrm{M}$. However, some of these complexes displayed high $\mathrm{IC}_{50}$ values due to selectivity or low cytotoxic activity as the case may be.

In general, the organotin complexes with the disubstituted alkyl/aryltin(IV) groups induced better cytotoxic activity than their mono-substituted derivatives [46, 47]. The phenyltin(IV) derivatives $\left(\mathrm{PhSnClL}_{2}\right.$ and $\left.\mathrm{Ph}_{2} \mathrm{SnL}_{2}\right)$ showed outstanding activities when compared with the standard drug 5FU. In some cases, mono-substituted alkyl/aryltin complexes showed good activities, especially in those of butyl and phenyl derivatives. Possible structural-activity relationships showed that all the complexes have outstanding cytotoxic activities, except complex $\mathrm{MeSnClL}_{2}$, which gave an $\mathrm{IC}_{50}$ value greater than $4000 \mu \mathrm{M}$. Complex $\mathrm{Ph}_{2} \mathrm{SnL}_{2}$ showed the best activity among this group of organotin(IV) dithiocarbamate compounds, with an $\mathrm{IC}_{50}$ value of $0.01 \mu \mathrm{M}$, which was better compared to the standard drug (5FU). This has been attributed to the improved lipophilicity due to the presence of one or more phenyl groups in the complexes. The order of activity for this group thus follows:

$$
\begin{aligned}
& \mathrm{Ph}_{2} \mathrm{SnL}_{2}>\mathrm{PhSnClL}_{2}>\mathrm{BuSnClL}_{2}> \\
& \mathrm{Bu}_{2} \mathrm{SnL}_{2}>\mathrm{Me}_{2} \mathrm{SnL}_{2}>\mathrm{MeSnClL}_{2} \\
& \text { Increasing order of cytotoxicity }
\end{aligned}
$$

Several mechanisms have been presented for the possible mode of action of anticancer drugs [48]. However, the lipophilicity of this drug plays a crucial role in their interaction with the cells. An increase in the length of the carbon chain in organotin(IV) compounds often increase its cytotoxicity toward cancerous cells $[23,49]$. The nature of the alkyl/aryl group on the tin metal center often influences lipophilicity. The phenyl group in an organotin molecule can induce $\pi-\pi$ interaction with biomolecular cells, which also contributes to the enhanced lipophilicity [23]. Also, the nature of the ligand moiety is important in their functionality as useful biological molecules [50]. Other possible routes of interaction/mechanism with cancerous cells have been proposed. These include interaction with nitrogenous bases, which consequently interferes with the DNA replication and transcription or by affecting the multi-enzymes complexes, which also helps in DNA transcription and replication, thereby inhibiting cell proliferation [11]. Therefore, DNA may likely be the targets of these complexes as reported in literature [51].

The cytotoxic activity observed for these complexes against the HeLa cell line generally indicated remarkable anti-tumoral activity. They have possible potential, upon further optimizations/modifications and testing in other cells lines, as lead compounds in the fight against cancerous diseases.

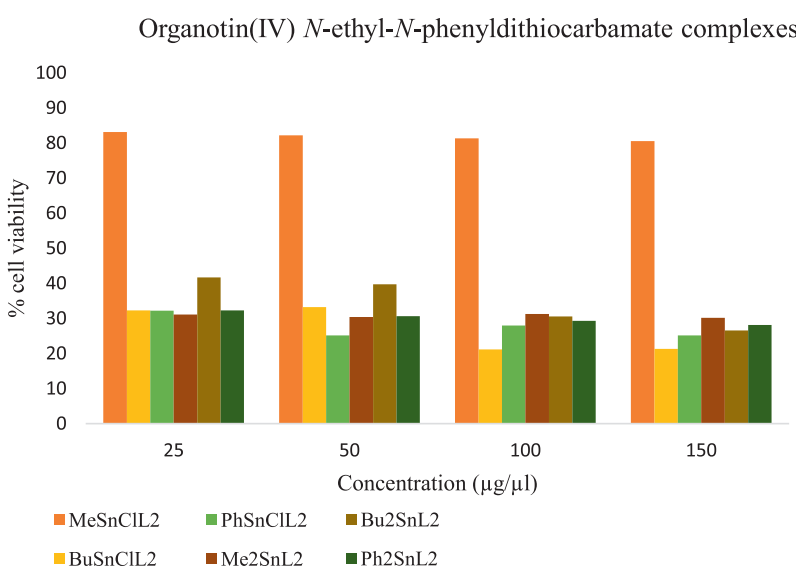

Fig. 2. Histogram representation of the percentage (\%) cell viability to concentration for the complexes. 


\section{Conclusions}

The evaluation of the antimicrobial and cytotoxic activities of the complexes has been achieved. These complexes showed good activity against a wide range of bacterial [both Gram positive $(+)$ and negative (-)] and two fungi organisms, with complexes bearing the phenyl group $\left(\mathrm{PhSnClL}_{2}\right.$ and $\left.\mathrm{Ph}_{2} \mathrm{SnL}_{2}\right)$ showing the best activities due to the lipophilic nature of their molecules in a biological system. These complexes, through a weak intermolecular contact with cell membranes, may alter the cell membrane of the organisms, thus causing death by interrupting the transportation of useful nutrients into their cell by deprivation. Similarly, the cytotoxicity study of these complexes favours the molecules with longer chains and those of aryl derivatives due to the increased lipophilicity upon complexation. The complexes $\mathrm{PhSnClL}_{2}$ and $\mathrm{Ph}_{2} \mathrm{SnL}_{2}$ exceptionally showed good selectivity toward the HeLa cell line, with outstanding activities better than the standard 5-Fluorouracil drug used. From the relationship deduced from the structural-activity of the complexes, it is apparent that the biological activity of organotin(IV) dithiocarbamate complexes is highly influenced by the number and the nature of alkyl/aryl group attached to the tin in addition to the lipophilicity and selectivity. The results obtained in this study showed that these complexes, upon further screening in vivo, may lead to the development of a new class of drugs which are potent against cancer cells and also act as a broad spectrum antimicrobial agent.

\section{Conflict of Interest}

The authors declare no conflict of interest.

\section{References}

1. SALAS P.F., HERRMANN C., ORVIG C. Metalloantimalarials. Chemical Reviews, 113 (5), 3450, 2013.

2. DEEPTHI B., BABU I.S., VENKATESH P., SHARFUDEEN S., SOUMYA V. Metal Complexes in Drug Research - A Review. J. Chem. Pharm. Res., 2 (4), 496, 2010.

3. CASINI A. Exploring the mechanisms of metal-based pharmacological agents via an integrated approach. Journal of Inorganic Biochemistry, 109, 97, 2012.

4. PATTAN S.R., PAWAR S.B., VETAL S.S., GHARATE U. D., BHAWAR S.B. The scope of metal complexes in drug design - A review. Indian Drugs, 49 (11), 5, 2012.

5. OBALEYE J.A., TELLA A.C., BAMIGBOYE M.O. Metal Complexes as Prospective Antibacterial Agents. A Search for Antibacterial Agents, 197, 2012.

6. HOGARTH G. Transition Metal Dithiocarbamates: 1978-2003. In Progress in Inorganic Chemistry, John Wiley \& Sons, Inc. London, 53, 1, 2005.

7. HOGARTH G. Metal-dithiocarbamate. Mini reviews in medicinal chemistry, 12 (12), 1202, 2012.
8. MENEZES D.C., VIEIRA F.T., DE LIMA G.M., PORTO A.O., CORTÉS M.E., ARDISSON J.D., ALBRECHT-SCHMITT T.E. Tin(IV) complexes of pyrrolidinedithiocarbamate: synthesis, characterisation and antifungal activity. European Journal of Medicinal Chemistry, 40 (12), 1277, 2005.

9. BAUL T.S.B. Antimicrobial activity of organotin(IV) compounds: A review. Applied Organometallic Chemistry, 22 (4), 195, 2008.

10. SADIQ-UR-REHMAN SADIA S.K., CHOUDHARY M.A., YASIN K.A., SAFDAR M., JOURNAL A. Synthesis, Characterization and Biological Studies of Organotin (IV) Thiocarbamates. Asian Journal of Chemistry, 23 (4), 1497, 2011.

11. SIRAJUDDIN M., SHAHEEN F., SIRAJUDDIN M., ALI S. carbodithioates: Synthesis, characterization and biological activities carbodithioates: Synthesis, characterization and biological activities. Journal of Organometallic Chemistry, 856 (12), 13, 2017.

12. MAHATO M., MUKHERJI S., VAN HECKE K., HARMS K., GHOSH A., NAYEK H.P. Mononuclear homoleptic organotin(IV) dithiocarbamates: Syntheses, structures and antimicrobial activities. Journal of Organometallic Chemistry, 853, 27, 2017.

13. REGIEL-FUTYRA A., DĄBROWSKI J.M., MAZURYK O., ŚPIEWAK K., KYZIOŁ A., PUCELIK B., STOCHEL G. Bioinorganic antimicrobial strategies in the resistance era. Coordination Chemistry Reviews, 351, 76, 2017.

14. TIAN L., LIU X., ZHENG X., SUN Y., YAN D., TU L. Synthesis, characterization and cytotoxic activity of new diorganotin(IV) complexes of N-(3,5-dibromosalicylidene) tryptophane. Applied Organometallic Chemistry, 25 (4), 298, 2011.

15. ADEYEMI J.O., ONWUDIWE D.C., EKENNIA A.C., ANOKWURU C.P., NUNDKUMAR N., SINGH M., HOSTEN E.C. Synthesis, characterization and biological activities of organotin(IV) diallyldithiocarbamate complexes. Inorganica Chimica Acta, 485, 64, 2019.

16. ADEYEMI J.O., ONWUDIWE D.C., SINGH M. Synthesis, characterization, and cytotoxicity study of organotin(IV) complexes involving different dithiocarbamate groups. Journal of Molecular Structure, 1179, 366, 2019.

17. AWANG N., MOKHTAR N., ZIN N.M. Research Article Antibacterial activity of organotin (IV) methyl and ethyl cylohexyldithiocarbamate compounds. Journal of Chemical and Pharmaceutical Research, 7 (8), 379, 2015.

18. SHAHZADI S., AHMAD S.U., ALI S., YAQUB S., AHMED F. Chloro-diorganotin(IV) complexes of pipyridyl dithiocarbamate: Syntheses and determination of kinetic parameters, spectral characteristics and biocidal properties. Journal of the Iranian Chemical Society, 3 (1), 38, 2006.

19. ZIA-UR-REHMAN MUHAMMAD N., ALI S., BUTLER I.S., MEETSMA A. Synthesis, spectroscopic properties, $\mathrm{X}$-ray single crystal analysis and antimicrobial activities of organotin(IV) 4-(4-methoxyphenyl)piperazine-1carbodithioates. Inorganica Chimica Acta, 376 (1), 381, 2011.

20. ADEYEMI J.O., ONWUDIWE D.C., EKENNIA A.C., UWAOMA R.C., HOSTEN E.C. Synthesis, characterization and antimicrobial studies of organotin(IV) complexes of $N$-methyl- $N$-phenyldithiocarbamate. Inorganica Chimica Acta, 477, 148, 2018.

21. LIU K., YAN H., CHANG G., LI Z., NIU M., HONG M. Organotin(IV) complexes derived from hydrazone Schiff base: Synthesis, crystal structure, in vitro cytotoxicity and 
DNA/BSA interactions. Inorganica Chimica Acta, 464, 137, 2017.

22. IQBAL H., ALI S., SHAHZADI S. Anti-inflammatory and Acute Toxicity Study of Organotin (IV) Complexes: A Review. Chemistry Journal, 06 (01), 59, 2016.

23. KADU R., ROY H., SINGH V.K. Diphenyltin(IV) dithiocarbamate macrocyclic scaffolds as potent apoptosis inducers for human cancer HEP $3 \mathrm{~B}$ and IMR 32 cells: synthesis, spectral characterization, density functional theory study and in vitro cytotoxicity. Applied Organometallic Chemistry, 29 (11), 746, 2015.

24. BAWAB A. AL, BOZEYA A., ODEH F. Synthesis, Characterization and Biological Activity of Organotin(IV) Complexes featuring di-2-ethylhexyldithiocarbamate and N-methylbutyldithiocarbamate as Ligands. GSTF International Journal of Chemical Sciences, 1 (2), 32, 2014.

25. CABALLERO A.B., SALAS J.M., SÁNCHEZ-MORENO M. Metal-Based Therapeutics for Leishmaniasis. MetalBased Therapeutics for Leishmaniasis, (Iv), 1. 2014.

26. ADEYEMI J.O., ONWUDIWE D.C., HOSTEN E.C. Organotin(IV) complexes derived from $\mathrm{N}$-ethyl- $\mathrm{N}$ phenyldithiocarbamate: Synthesis, characterization and thermal studies. Journal of Saudi Chemical Society, 22 (4), 427, 2018.

27. ROSS P.W., MALBROOK W.P. Clinical and oral microbiology. New York: Hemispher Publishing Corporation. 1982.

28. BALOUIRI M., SADIKI M., IBNSOUDA S.K. Methods for in vitro evaluating antimicrobial activity: A review. Journal of Pharmaceutical Analysis, 6 (2), 71, 2016.

29. FERNÁNDEZ-TORRES B., INZA I., GUARRO J. Evaluation of Disk Diffusion Method for Determining Eberconazole Susceptibility of Dermatophytes and Influence of Culture Medium. Antimicrobial Agents And Chemotherapy, 49 (5), 2116, 2005.

30. SIMON H.J., YIN E.J. Microbioassay of antimicrobial agents. Applied microbiology, 19 (4), 573, 1970.

31. ALVES T.M. DE A., SILVA A.F., BRANDÃO M., GRANDI T.S.M., SMÂNIA E. DE F.A., SMÂNIA JÚNIOR A., ZANI C.L. Biological screening of Brazilian medicinal plants. Memórias do Instituto Oswaldo Cruz, 95 (3), 367, 2000.

32. SILVA A.C.O., SANTANA E.F., SARAIVA A.M., COUTINHO F.N., CASTRO R.H.A., PISCIOTTANO M.N.C., ALBUQUERQUE U.P. Which Approach Is More Effective in the Selection of Plants with Antimicrobial Activity? Evidence-Based Complementary and Alternative Medicine, 2013 (C), 1, 2013.

33. ADLI H.K., SIDEK N.M., ISMAIL N., KHAIRUL W.M. Several Organotin(IV) Complexes Featuring 1-Methylpiperazinedithiocarbamate and N -Methylcyclohexyldithiocarbamate as Ligands and Their Anti-Microbial Activity Studies. Chiang Mai J. Sci., 40 (1), 117, 2013.

34. ZAFARIAN H., SEDAGHAT T., MOTAMEDI H., TRZYBIŃSKI D., WOŹNIAK K. Bis-diorganotin(IV) complexes with binucleating hydrazones derived from a methylene-bis-aromatic aldehyde as linker: Synthesis, spectral and structural characterization, antibacterial activity and DNA cleavage studies. Journal of Organometallic Chemistry, 853, 184, 2017.

35. SEDAGHAT T., TAHMASBI L., MOTAMEDI H., REYES-MARTINEZ R., MORALES-MORALES D. Diorganotin(IV) complexes with furan-2-carbohydrazone derivatives: synthesis, characterization, crystal structure and antibacterial activity. Journal of Coordination Chemistry, 66 (4), 712, 2013.

36. PELLERITO C., NAGY L., PELLERITO L., SZORCSIK A. Biological activity studies on organotin(IV) $\mathrm{n}+$ complexes and parent compounds. Journal of Organometallic Chemistry, 691 (8), 1733, 2006.

37. SEDAGHAT T., AMINIAN M., AZARKISH M. New Bis-Diphenyltin(IV) Complexes With Oxalyldihydrazone Derivatives: Synthesis, Characterization And Antibacterial Activity. Phosphorus, Sulfur, and Silicon and the Related Elements, 190 (3), 352, 2015.

38. SHAHEEN F., ZIA-UR-REHMAN ALI S., MEETSMA A. Structural properties and antibacterial potency of new supramolecular organotin(IV) dithiocarboxylates. Polyhedron, 31 (1), 697, 2012.

39. BARBOSA A.S.L., GUEDES J. DE S., DA SILVA D.R., MENEGHETTI S.M.P., MENEGHETTI M.R., DA SILVA A.E., MENDONÇA-JUNIOR F.J.B. Synthesis and evaluation of the antibiotic and adjuvant antibiotic potential of organotin(IV) derivatives. Journal of Inorganic Biochemistry, 180 (12), 80, 2018.

40. EKENNIA A.C., ONWUDIWE D.C., OSOWOLE A.A., OLASUNKANMI L.O., EBENSO E.E. Synthesis, Biological, and Quantum Chemical Studies of $\mathrm{Zn}(\mathrm{II})$ and $\mathrm{Ni}(\mathrm{II})$ Mixed-Ligand Complexes Derived from N,NDisubstituted Dithiocarbamate and Benzoic Acid. Journal of Chemistry, 2016, 1, 2016.

41. JABBAR S., SHAHZADI I., REHMAN R., IQBAL H., QURAT-UL-AIN JAMIL A., QANUNGO K. Synthesis, characterization, semi-empirical study, and biological activities of organotin(IV) complexes with cyclohexylcarbamodithioic acid as biological active ligand. Journal of Coordination Chemistry, 65 (4), 572, 2012.

42. ANJANEYULU Y., RAO R.P. Preparation, characterization and antimicrobial activity studies on some ternary complexes of $\mathrm{Cu}$ (II) with acetylacetone and various salicylic acids. Synthesis and Reactivity in Inorganic and Metal-Organic Chemistry, 16 (2), 257, 1986.

43. JAVED F., SIRAJUDDIN M., ALI S., KHALID N., TAHIR M.N., SHAH N.A., KHAN M.R. Organotin(IV) derivatives of o-isobutyl carbonodithioate: Synthesis, spectroscopic characterization, X-ray structure, HOMO/ LUMO and in vitro biological activities. Polyhedron, 104, 80, 2016

44. PRABHAKARAN R., GEETHA A., THILAGAVATHI M., KARVEMBU R., KRISHNAN V., BERTAGNOLLI H., NATARAJAN K. Synthesis, characterization, EXAFS investigation and antibacterial activities of new ruthenium(III) complexes containing tetradentate Schiff base. Journal of Inorganic Biochemistry, 98 (12), 2131, 2004.

45. DIAS L.C., DE LIMA G.M., TAKAHASHI J.A., ARDISSON J.D. New di- and triorganotin(IV) carboxylates derived from a Schiff base: synthesis, characterization and in vitro antimicrobial activities. Applied Organometallic Chemistry, 29 (5), 305, 2015.

46. TIEKINK E.R.T. Tin dithiocarbamates: Applications and structures. Applied Organometallic Chemistry, 22 (9), 533, 2008.

47. YANG Y., HONG M., XU L., CUI J., CHANG G., LI D., LI C.Z. Organotin(IV) complexes derived from Schiff base N'-[(1E)-(2-hydroxy-3-methoxyphenyl) methylidene]pyridine-3-carbohydrazone: Synthesis, in vitro cytotoxicities and DNA/BSA interaction. Journal of Organometallic Chemistry, 804, 48, 2016. 
48. ZHANG P., SADLER P.J. Advances in the design of organometallic anticancer complexes. Journal of Organometallic Chemistry, 839, 5, 2017.

49. HADJIKAKOU S.K., HADJILIADIS N. Antiproliferative and anti-tumor activity of organotin compounds. Coordination Chemistry Reviews, 253 (1-2), 235, 2009.

50. HARRISON P. Chemistry of Tin. (Peter J. Smith, Ed.)

(Second edi.). London: Springer Science+Business Media Dordrecht. 1998.
51. SHAHEEN F., SIRAJUDDIN M., ALI S., ZIA-URREHMAN DYSON P.J., SHAH N.A., TAHIR M.N. Organotin(IV) 4-(benzo[d][1,3]dioxol-5-ylmethyl) piperazine-1-carbodithioates: Synthesis, characterization and biological activities. Journal of Organometallic Chemistry, 856, 13, 2018. 